\title{
Sociodemographic, maternal and clinical conditions of children exposed to the human immunodeficiency virus
}

\author{
Condições sociodemográfica, materna e clínica de crianças expostas ao vírus da \\ imunodeficiência humana \\ Condiciones sociodemográfica, materna y clínica de niños expuestos al virus de la \\ inmunodeficiencia humana
}

Marli Teresinha Gimeniz Galvãoํㅜㄹ Gilmara Holanda da Cunha1, Julyana Gomes Freitas², Elucir Gir ${ }^{3}$, Renata Karina Reis3

This was a quantitative, descriptive cross-sectional study aiming to identify the sociodemographic, maternal and clinical conditions of children exposed to the Human Immunodeficiency Virus, who were treated in a reference hospital for infectious diseases in Fortaleza-Ceará. The sample consisted of 117 mothers who brought their children for consultation between July and December 2009. Data were collected through a semi-structured interview form. There was a higher percentage of mothers aged 20-29 years (53.8\%), married (73.5\%) and unemployed (68.3\%). Most children were less than 12 months old (39.4\%), did not receive governmental assistance (66.6\%), and did not attend the health service on the scheduled date (77.0\%). Some mothers did not use Zidovudine during pregnancy (15.4\%), and eight children did not use it after birth (6.8\%). Nineteen children did not use prophylaxic Trimethoprim-Sulfametaxazol in the first year of life. It was concluded that most children had socioeconomic difficulties that negatively influenced their health conditions.

Descriptors: HIV; Acquired Immunodeficiency Syndrome; Child; Social Conditions.

Estudo transversal, descritivo e quantitativo, com objetivo de identificar as condições sociodemográfica, materna e clínica de crianças expostas ao Vírus da Imunodeficiência Humana atendidas em hospital de Fortaleza-Ceará, Brasil. A amostra compôs-se das 117 mães que levaram seus filhos para consulta entre julho e dezembro de 2009. Os dados foram coletados em entrevista com formulário semiestruturado. Constatou-se maior percentual de mães na faixa etária de 20-29 anos $(53,8 \%)$, casadas $(73,5 \%)$ e desempregadas (68,3\%). A maioria das crianças possuía menos de 12 meses de idade (39,4\%), não recebiam auxílio governamental $(66,6 \%)$ e não compareciam ao serviço de saúde na data agendada (77,0\%). Algumas mães não utilizaram Zidovudina na gestação $(15,4 \%)$ e oito crianças não utilizaram após o nascimento $(6,8 \%)$. Dezenove crianças não fizeram profilaxia com Sulfametaxazol-Trimetoprima no primeiro ano de vida. Concluiu-se que a maioria das crianças possui dificuldades socioeconômicas que influenciam negativamente nas condições de saúde.

Descritores: HIV; Síndrome de Imunodeficiência Adquirida; Criança; Condições Sociais.

Estudio transversal, descriptivo y cuantitativo, con objetivo de determinar las condiciones sociodemográfica, materna y clínica de niños expuestos al Vírus de la Inmunodeficiencia Humana en hospital de Fortaleza-Ceará, Brasil. La muestra fue compuesta por 117 madres que llevaron sus hijos a consulta entre julio y diciembre de 2009. Los datos fueron recolectados en entrevista semiestructurada. Hubo mayor porcentaje de madres de 20-29 años (53,8\%), casadas (73,5\%) y desempleadas (68,3\%). La mayoría de los niños tenían menos de 12 meses de edad (39,4\%), no recibían ayuda gubernamental (66,6\%) y no comparecían a los servicios de salud en la fecha prevista (77,0\%). Algunas madres no utilizaron Zidovudina durante el embarazo $(15,4 \%)$ y ocho niños no usaban después del nacimiento $(6,8 \%)$. Diecinueve niños no hicieron la profilaxis con Trimetoprima-Sulfametaxazol en el primer año de vida. En conclusión, la mayoría de los niños presentaba dificultades socioeconómicas que influenciaban negativamente en las condiciones de salud.

Descriptores: VIH; Síndrome de Inmunodeficiencia Adquirida; Niño; Condiciones Sociales.

\footnotetext{
${ }^{1}$ Universidade Federal do Ceará. Fortaleza, CE, Brazil.

${ }^{2}$ Universidade de Fortaleza. Fortaleza, CE, Brazil.

${ }^{3}$ Universidade de São Paulo, Ribeirão Preto, SP, Brazil.

Corresponding author: Marli Teresinha Gimeniz Galvão

Rua Alexandre Baraúna, 1115, Rodolfo Teófilo. CEP: 60430-160. Fortaleza, CE, Brazil. E-mail: marligalvao@gmail.com
} 


\section{Introduction}

Described as a complex issue, infection with the Human Immunodeficiency Virus (HIV) and Acquired Immunodeficiency Syndrome (AIDS) can occur in any individual, regardless of gender, social class, race, religion, among others, leading to changes in biological, social and psychological aspects of the people affected and those people close to them ${ }^{(1-2)}$.

Studies evidence that the number of women with HIV has been increasing and most women are infected during the childbearing age, leading to a significant rate of pregnant women in this situation and therefore, a large number of children born who have been exposed to or infected with HIV. Thereby, the tendency of mother-to-child transmission or vertical transmission (VT) increases ${ }^{(3-4)}$.

The most effective way to reduce VT of HIV is early diagnosis, as in other diseases. The expansion of rapid testing for HIV and other maternal serological tests are crucial, because they minimize the risk of virus transmission. Treatment with antiretroviral drugs during pregnancy is also important. If pregnant women living with HIV have adequate clinical care and adhere to treatment, they can prevent infection in the infant, improve their health, and prepare physically and psychologically to deliver their infants ${ }^{(1,5)}$.

At the beginning of the AIDS epidemic, due to the lack of efficient therapeutic methods, expectations of survival for infected children were restricted. With the advent of antiretroviral drugs and the greater interest of the authorities regarding the health and well-being of these children and their families, the situation was changed, and there was increased survival and better quality of life for this population ${ }^{(3-4)}$.

As demonstrated by Protocol 076 Pediatric AIDS clinical trial group (PACTG), in order to reduce VT of HIV, the use of azidothymidine (AZT) is recommended after 14 weeks of pregnancy; intravenous AZT in pregnant women is given during labor and childbirth until umbilical cord clamping ${ }^{(5)}$. For newborns exposed to HIV, substitution of breastfeeding by formula and other foods, according to the child's age, are indicated; AZT syrup $10 \mathrm{mg} / \mathrm{mL}$ is given, preferably starting prior to the second postpartum hour, $2 \mathrm{mg} /$ Kg every six hours for six weeks. From the fourth to sixth weeks of life until definitive diagnosing of HIV infection, children should receive chemoprophylaxis for Pneumocystis jiroveci (former Pneumocystis carinii) with sulfamethoxazole (SMX) associated with trimethoprim (TMP), $25-40 \mathrm{mg} / \mathrm{Kg} /$ day SMX or $5-10 \mathrm{mg} / \mathrm{Kg} /$ day TMP, split into two daily doses three times a week, or every other day ${ }^{(5-6)}$.

Children born exposed to HIV are considered to be at risk. Therefore, it is of great importance to monitor the care of children in consultations scheduled in the specialized care service and ensure that those responsible are receiving free infant milk formula, so that they are not breastfed ${ }^{(6)}$. Periodic monitoring in specialized services with trained pediatricians should be maintained at least until establishment of the diagnosis. Consultations should be monthly for the first six months and quarterly from the second half of life. If HIV infection is confirmed, treatment will continue in those services. Children without a seropositive diagnosis can be monitored in primary health care ${ }^{(7)}$.

In Brazil, most individuals living with HIV/ AIDS have unfavorable living conditions, with low education and low income ${ }^{(3)}$. This fact undermines the access to population health services, and increases financial difficulties due to unemployment and illness. Health conditions are directly associated with the individuals' social conditions. Therefore, health promotion, prevention, rehabilitation and recovery are linked to the conditions presented by the individual, in this case, the child ${ }^{(8)}$.

Coping, vulnerability and the conditions established to manage living with HIV are problems faced by the children's mothers - both those with the disease and those exposed to the virus - and sometimes by the children themselves. Because mothers constantly encourage their children, take them to regular hospital consultations, assist them 
with necessary medications, accompany them to exams, they assume a vital role in promoting health and taking care of the child. Antiretroviral treatment of the mother during pregnancy and childbirth, as well as during postpartum follow-up, is a decisive initiative. In addition to care by specialized professionals and other family members, whose measures are essential to achieving a healthy social, psychological and physical life.

Considering the above, the present study aimed to characterize the sociodemographic, maternal and clinical conditions of children born exposed to HIV who are treated in a reference service for infectious diseases in Fortaleza-Ceará. This study is important for better understanding of the characteristics of these children and can subsidize holistic nursing care directed to existing needs.

\section{Method}

This is a quantitative, descriptive-exploratory, cross-sectional study conducted at Hospital São José de Doenças Infecciosas (HSJDI), a reference in the care of people living with HIV/AIDS throughout the state of Ceará, located in the city of Fortaleza. The service offers consultations, laboratory and radiologic tests, antiretroviral drugs, condoms, outpatient and inpatient units. It should be noted that this study is part of a broader research project that assessed the health conditions, family and community life of children born at risk of vertical transmission of HIV or living with HIV/AIDS in Fortaleza-CE.

The study was performed from July to December of 2009. The sample consisted of 117 mothers who took their children for follow-up consultations at the hospital during the study period. Inclusion criteria adopted for mothers and children were: 1 . Mother: having given birth to at least one child while having an HIV infection; and, signing of the Informed Consent Form (ICF); 2. Child: born exposed to HIV; cared for by biological mother; and followed up in the health service. Exclusion criteria comprised the presence of mental illness of the mother or any other condition that could interfere with responses to the questions prepared by the researcher.

Data were collected by a trained interviewer, by completing a semi-structured questionnaire covering different aspects, among them: family and environmental characteristics, and care provided to children born exposed to HIV. The health status of the child, as well as follow-up in a specialized clinic, were also assessed from the perspective of the person responsible.

In order to meet the study's aim, the following maternal variables were analyzed: age, self-reported race, education, marital status, occupational status, religion, and economic status. In order to meet and clarify the purpose of the study the following maternal variables were analyzed. For the socioeconomic classification, the Brazil Economic Classification Criterion (BECC) was used, which examines families in categories according to consumption patterns or potentials using a socioeconomic scale, through assignment of weights to a set of items, such as domestic comfort and level of education of the head of household ${ }^{(9)}$. The BECC is presented through five classes, designated A, B, C, D and E. Class A is the one possessing optimum conditions, therefore Class $\mathrm{E}$ has negligible conditions for survival.

For the children, the variables adopted were: age (in months), gender, race, result of last antiHIV serology testing, governmental assistance, use of other health services, attendance at follow-up appointments on the date scheduled, submission to required exams, age of the first consultation of the child in the specialized service, start of AZT use by the mother during pregnancy, start of AZT use by the child, person responsible for the administration of AZT to the child, use of Trimethoprim-Sulfametaxazol during the first year of life, maternal perception of the child's health status.

All mothers were invited to participate in the study while they waited for their children to be attended. The interviews had a mean duration of 60 
minutes and were conducted in a private room in order to ensure the confidentiality of information and maintain privacy and spontaneity of the mothers.

Data obtained were tabulated in Excel. Descriptive statistics and analysis of the associations between the variables, "Brazil Economic Classification Criterion" and "mother's education" with "children's attendance to follow-up appointment on the date scheduled" and "children's submission to required exams", using the Fisher's exact test, were calculated. For such analyses, a $0.05(5 \%)$ probability of type I error (significance level) was established. A p-value $<0.05$ was considered statistically significant.

STATA software version 10.0 was used for data processing. Results were expressed as absolute and relative frequencies, and association of variables, and subsequently discussed from the perspective of the literature available.

The research project was submitted to the HSJDI Ethics Committee, in accordance with Resolution n. 196/96 of the National Health Council on research with human subjects and approved on 6/18/2007 under Protocol n. 014/2007. The study was conducted according to the ethical principles required. All participants signed an informed consent form. The confidentiality of the identification of participants was maintained and data were used only for scientific purposes.

\section{Results}

Regarding the sociodemographic characteristics of the 117 mothers with children born exposed to HIV, it was found that the age ranged from 18 to 42 years, with a mean age of 28 years. About race, $71.0 \%$ reported being of mixed race (brown). Regarding education, 29.0\% were illiterate. Most were married or had a stable union $(73.5 \%)$, and were unemployed at the time of the study (68.3\%). As for religion, $75.2 \%$ were Catholic, and $68.3 \%$ of families were in Classes " $D$ " and " $E$ ", therefore most children lived in environments with minimal access to consumer goods and economic resources. These data are presented in Table 1.

Table 1 - Sociodemographic characteristics of 117 mothers of children born exposed to HIV

\begin{tabular}{|c|c|}
\hline Maternal characteristics & n (\%) \\
\hline \multicolumn{2}{|l|}{ Age (years)* } \\
\hline$\leq 19$ & $4(3.4)$ \\
\hline $20-29$ & $63(53.8)$ \\
\hline $30-39$ & 45 (38.5) \\
\hline$\geq 40$ & $5(4.3)$ \\
\hline \multicolumn{2}{|l|}{ Self-reported race } \\
\hline White & $23(19.6)$ \\
\hline Black & $6(5.1)$ \\
\hline Asian & $5(4.3)$ \\
\hline Mixed-race (Brown) & $83(71.0)$ \\
\hline \multicolumn{2}{|l|}{ Education } \\
\hline Illiterate & $34(29.0)$ \\
\hline 1st to 3rd grade of elementary school & $26(22.3)$ \\
\hline 4th to 8 th grade of elementary school & $51(43.6)$ \\
\hline High school & $6(5.1)$ \\
\hline \multicolumn{2}{|l|}{ Marital status } \\
\hline Married/Stable union & $86(73.5)$ \\
\hline Single & $20(17.0)$ \\
\hline Separate/Divorced & $11(9.5)$ \\
\hline \multicolumn{2}{|l|}{ Occupational status } \\
\hline Employed & $11(9.5)$ \\
\hline Unemployed & $80(68.3)$ \\
\hline Housewife & $9(7.7)$ \\
\hline Non-reported & $17(14.5)$ \\
\hline \multicolumn{2}{|l|}{ Religion } \\
\hline Catholic & $88(75.2)$ \\
\hline Evangelical & $18(15.3)$ \\
\hline Other & $11(9.5)$ \\
\hline \multicolumn{2}{|l|}{ Economic Classification** } \\
\hline B & $2(1.7)$ \\
\hline $\mathrm{C}$ & $35(30.0)$ \\
\hline $\mathrm{D}$ & $51(43.5)$ \\
\hline ( & $29(24.8)$ \\
\hline
\end{tabular}

When mothers were asked about HIV serological testing of the children's father, 79 women reported knowing about it. Of those, 31 (39.2\%) reported that the fathers had a positive serology for HIV and 28 (35.4\%) reported a negative serology. Twenty parents (25.4\%) were unaware of their HIV status because they had not yet undergone serology. 
Table 2 shows the epidemiological characteristics of children born exposed to HIV. The majority (39.4\%) was less than 12 months old and over half (55.5\%) were female. With regard to race, 99 (84.6\%) were mixed race (brown). Regarding Anti-HIV serology, information was obtained through mothers' statements and analysis of the children's exams. It is noteworthy that although many mothers could have their children monitored in other health units, they preferred the specialized service because it reduces the chances of having the diagnosis revealed to others, thereby minimizing the stigma and prejudice resulting from HIV infection. Regarding the child AntiHIV serology, 30 (25.6\%) had a positive diagnosis of HIV infection. At the time of interview, 28 children had not yet had anti-HIV serology. About any type of government assistance, only 36 children (31.86\%) were supported by Programa Bolsa Família (Family Grant Program). Moreover, all children received free formula, in order to prevent being breastfed.

Table 2 - Epidemiological characterization of 117 children born exposed to HIV

\begin{tabular}{lc}
\hline Children characteristics & n (\%) \\
\hline Age (months) & \\
$<12$ & $46(39.4)$ \\
$12-23$ & $41(35.0)$ \\
$24-35$ & $30(25.6)$ \\
Gender & \\
Male & $52(44.5)$ \\
Female & $65(55.5)$ \\
Race & \\
White & $10(8.6)$ \\
Mixed (Brown) & $99(84.6)$ \\
Black and Asian & $8(6.8)$ \\
Diagnosis (last Anti-HIV serology) & \\
HIV+ & $30(25.6)$ \\
HIV- & $59(50.4)$ \\
Undefined & $28(24.0)$ \\
Government assistance & \\
Yes & $39(33.4)$ \\
No & $78(66.6)$ \\
\hline
\end{tabular}

Regarding the use of health services concomitant with the specialized one, 56 mothers (47.8\%) reported use of the Family Health Strategy and only four mothers (3.4\%) reported using private service/ health insurance for any type of child health care. Only 27 mothers (23.0\%) attended the consultations on the scheduled date, however, the ones who did not attend it identified a lack of transportation and financial difficulties.

Concerning laboratory tests for monitoring VT of HIV, which include anti-HIV serology, TCD4+ lymphocytes and viral load, 100 children (85.5\%) had been submitted according to the health service request. Regarding age at which children were first referred to the service after delivery, 82 (70.0\%) of the mothers indicated this occurred during the first month of life. Most mothers were very worried about the definition of the child's anti-HIV serological testing, so they attended appointments, as much as possible. Delays or absences were due to lack of financial resources. See Table 3.

Table 3 - Use of health services by children born exposed to HIV

\begin{tabular}{lc}
\hline Use of health services & n (\%) \\
\hline $\begin{array}{l}\text { Use of health services concomitant with the } \\
\text { specialized service }\end{array}$ & $56(47.8)$ \\
Family Health Program (PSF) & $4(3.4)$ \\
Private/Health insurance & $57(48.8)$ \\
No & \\
Attendance to follow-up on the date scheduled & $27(23.0)$ \\
Yes & $90(77.0)$ \\
No & \\
Submission to exams required & $100(85.5)$ \\
Yes & $17(14.5)$ \\
No & \\
Age of the first consultation of the child in the \\
specialized service
\end{tabular}


Table 4 - Variables related to the treatment of children born exposed to HIV

\begin{tabular}{|c|c|}
\hline Variables related to treatment & n (\%) \\
\hline \multicolumn{2}{|c|}{ Start of AZT use by the mother during pregnancy } \\
\hline 1st quarter & $35(30.0)$ \\
\hline 2nd quarter & $42(35.8)$ \\
\hline 3rd quarter & $14(12.0)$ \\
\hline Did not use & $18(15.4)$ \\
\hline After childbirth & $8(6.8)$ \\
\hline \multicolumn{2}{|l|}{ Start of AZT use by the child } \\
\hline In the first hours after birth & $100(85.4)$ \\
\hline After 24 hours from birth & $9(7.8)$ \\
\hline Did not use & $8(6.8)$ \\
\hline \multicolumn{2}{|c|}{$\begin{array}{l}\text { Person responsible for the administration of AZT to } \\
\text { the child }\end{array}$} \\
\hline Mother & $111(94.8)$ \\
\hline Others & $6(5.2)$ \\
\hline \multicolumn{2}{|c|}{$\begin{array}{l}\text { Use of Trimethoprim-Sulfametaxazol during the first } \\
\text { year of life }\end{array}$} \\
\hline Yes & 98 (83.7) \\
\hline No & $19(16.3)$ \\
\hline \multicolumn{2}{|c|}{ Maternal perception of the child's health status } \\
\hline Excellent & $46(39.3)$ \\
\hline Good & $59(50.4)$ \\
\hline Normal & $11(9.5)$ \\
\hline Bad & $1(0.8)$ \\
\hline
\end{tabular}

Standard pharmacological treatment should be provided by mothers and implemented in newborns for reduction of VT of HIV. Most mothers (35.8\%) started treatment with AZT in the second quarter of pregnancy, however, 18 (15.4\%) did not take the drug. It was found that AZT was not orally administered after birth to eight children. Moreover, in most cases (94.8\%), the mothers were the ones administering AZT to their children. Nineteen children (16.3\%) had not used Trimethoprim-Sulfametaxazol. Regarding the perception of mothers about the health of their children, most said that it was excellent or good, and only one $(0.8 \%)$ reported that her child's health was bad. Table 4 provides this data.

Table 5 shows the frequency with which mothers brought their children who were born exposed to HIV for follow-up appointments in the scheduled date, in addition to the exams required for the child. These two variables were analyzed according to the Brazil Economic Classification Criterion (BECC) and the mother's education.

The higher rate of attendance of mothers to follow-up consultations was statistically significant when they belonged to classes B or C, according to the BECC, when compared to mothers in classes D and $E(p<0.0001)$, i.e., mothers with the worst living conditions took their children less frequently to consultations. Moreover, the frequency of submission to exams required for the child was significantly higher ( $p=0.0013)$ among mothers in classes B or C than among mothers of classes $\mathrm{D}$ or $\mathrm{E}$.

It was also observed that illiterate mothers took their children for the follow-up consultations less frequently than literate mothers $(\mathrm{p}=0.0005)$. Moreover, submission to the exams required for the child was significantly lower $(\mathrm{p}<0.0001)$ among illiterate mothers than among literate mothers. 
Table 5 - Frequency of follow-up consultations of the children on the scheduled date and submission to exams required for the child, according to Brazil Economic Classification Criterion and mother's education

\begin{tabular}{|c|c|c|c|c|c|c|c|c|}
\hline \multirow[t]{2}{*}{ Variables } & \multicolumn{4}{|c|}{$\begin{array}{l}\text { Follow-up consultations of the children on the scheduled } \\
\text { date }\end{array}$} & \multicolumn{4}{|c|}{ Submission to exams required for the child } \\
\hline & Yes & No & Total & *p-value & Yes & No & Total & *p-value \\
\hline \multicolumn{9}{|c|}{ Brazil Economic Classification Criterion } \\
\hline $\mathrm{B} / \mathrm{C}$ & $25(67.6 \%)$ & $12(32.4 \%)$ & $37(100.0 \%)$ & $<0,0001$ & $37(100.0 \%)$ & $\begin{array}{c}0 \\
(0.0 \%)\end{array}$ & $37(100.0 \%)$ & 0.0013 \\
\hline $\mathrm{D} / \mathrm{E}$ & $\begin{array}{c}2 \\
(2.5 \%)\end{array}$ & $78(97.5 \%)$ & $80(100.0 \%)$ & & $63(78.7 \%)$ & $17(21.3 \%)$ & $80(100.0 \%)$ & \\
\hline \multicolumn{9}{|c|}{ Mother's education } \\
\hline Illiterate & $\begin{array}{c}1 \\
(2.9 \%)\end{array}$ & $33(97.1 \%)$ & $34(100.0 \%)$ & 0,0005 & $19(55.9 \%)$ & $15(44.1 \%)$ & $34(100.0 \%)$ & $<0.0001$ \\
\hline Literate & $26(31.3 \%)$ & $57(68.7 \%)$ & $83(100.0 \%)$ & & $81(97.6 \%)$ & $\begin{array}{c}2 \\
(2.4 \%)\end{array}$ & $83(100.0 \%)$ & \\
\hline
\end{tabular}

*Data analysed through Fisher's exact test

\section{Discussion}

The health conditions and lifestyle of a population characterize the ways the individuals exist within the social world. Such ways are evidenced by socioeconomic, political and cultural factors that will affect the behavior, biology and environment of these people, influencing their state of health/illness and, by extension, their quality of life. These social determinants have significant influence on children's lives, especially because they are in a phase of great vulnerability and dependence. There is a visible possibility of changes in their normal development, with consequent problems for their health. Given the situation, they require intensive care by adults and by health services in order to protect them and promote better quality of life ${ }^{(10-12)}$.

Similar to other studies, this study found that most individuals with HIV/AIDS live in a situation of poverty, low education and unemployment, factors that can negatively influence growth and development of children born exposed to $\mathrm{HIV}^{(3-}$ $4,10,12)$. It was also observed that some mothers had serodiscordant partners or they had not yet submitted to anti-HIV serology. A current situation posed by the HIV/AIDS epidemic is the phenomenon of "serodiscordance", which is the occurrence of emotional-sexual relationships between partners with different HIV serology. The term, along with others like serodivergence and serodifference, have existed since the mid-1990s in American and French medical articles. This type of relationship becomes increasingly common due to improvement of the quality of life expectancy of HIV-positive people, owing to the advent of antiretroviral drugs ${ }^{(4,13)}$.

It should be noted that the lack of parental resources, as well as the lack of government assistance, interfere directly and negatively in the treatment and monitoring of children born exposed to HIV. Although Brazil has a very organized national program for sexually transmitted diseases and AIDS in the three levels of care within the Unified Health system (SUS) - federal, state and local, which is internationally recognized and an example for the world for having a program that offers good responses to the HIV/AIDS epidemic, it is worth questioning the future sustainability and the extent to which Brazil has control over an epidemic that grows invisibly in its poor interior. An important indicator is access to antiretroviral drugs, because even if the treatment is offered for free, in many regions, the fact that people do not have enough to eat makes them unable to respond to therapy ${ }^{(10)}$.

Among the governmental initiatives directed 
toward STD/AIDS are the Ministry of Health manuals, which are directed at follow-up of children born exposed to HIV. These manuals are considered national benchmarks for the care of children and adolescents and have been periodically updated in accordance with the progress of science. Thereby, they offer professionals updates on treatment and management of various other aspects related to infection ${ }^{(3,5-6)}$. These documents also emphasize the need for bonding between the child, parents, caregivers and health professionals.

As noticed in this study, not all children born exposed to HIV made the first appointment at the reference service before the $30^{\text {th }}$ day of life. Different reasons may be involved in this absence or irregularity in the follow up of the child. Among them, maternal fear of revealing their serological condition or that of their children is emphasized, because one of the dilemmas experienced by women is disclosure of the diagnosis. They hide it due to the fear of being stigmatized and rejected. They often avoid reporting it to their own family, in order not to be victims of their prejudice ${ }^{(12,14)}$. Moreover, after the child's birth, mothers undergo numerous psychological and social experiences, such as fear of death and the possibility of leaving their children orphans, the prospect of having an HIV-positive child, and fear of social discrimination $^{(1)}$.

Care of the children is almost exclusively performed by the biological mothers, since they play the role of primary caregivers in the children`s development process. It is noteworthy that the relationships of socioeconomic, environmental, cultural, biological and subjective factors incorporate the dimensions in the health of each individual, with visible inequalities in production and consumption of social resources as determinants of health and disease. The incidence of individuals from less privileged economic class evidences inequalities, exposure to risk factors, and how vulnerable families live with $\operatorname{HIV}^{(2,4)}$.

Many children still had no conclusive diagnosis about HIV infection. Children born from mothers with HIV received anti-HIV IgG antibodies during pregnancy. All these children are seropositive for HIV at birth, and those not infected seroconvert on average between 9 and 12 months of age, and may remain with a positive test until 18 months of life. Children older than 18 months are considered noninfected when there is a nonreactive sample among the tests to detect anti-HIV antibodies, or a negative sample in two rapid tests. In case of discordant results in the first two exams, a third rapid test is performed. When the third test result is negative, the sample is considered "HIV negative"(5-6).

In the social and health contexts, family plays a key role as a provider of child care, because the infant depends on others to survive. In this family context, mothers play the role of provider and are responsible for effective communication with health professionals. They seek the best assistance and care, so that a greater health potential can be reached ${ }^{(15-16)}$.

It is therefore essential that the survival and health of children and their caregivers, i.e., mothers, are maintained and ensured. It is necessary to improve the conditions of care and access to health services, monitoring of treatment and support offering to those infected in order to ensure adequate assistance. These mentioned measures are essential to improving the quality of life of children. Associated with that, antiretroviral therapy has benefits for HIV-infected children and mothers' health ${ }^{(5-6)}$.

Over the last 10 years there has been a $11.1 \%$ decrease in AIDS mortality in Brazil, but according to regions, mortality has increased in the North, Northeast and South ${ }^{(3)}$. The reduction in morbidity and mortality has occurred due to the advent of antiretroviral drugs in 1996. Brazil was the first developing country to adopt a policy of public access to antiretroviral treatment, and internationally recognized as such by having a program that provides good responses against HIV/AIDS ${ }^{(17)}$.

The birth of children exposed to HIV is strongly associated with lack of prenatal care and the high 
rate of HIV in low-income areas. Several factors influence adherence to antiretroviral treatment, so that treatment regimens need to be well assessed for each individual. There is the need to observe the physiological, pathological, social and environmental characteristics of each person, especially related to the child, a fragile and vulnerable being, with greater limitations and dependent on care $^{(5-6)}$.

Therefore, treatment and more detailed, specific follow-up must be provided to them, strengthened by greater attention from health professionals and caregiver mothers. The importance of multidisciplinary healthcare teams is highlighted, which can provide adequate treatment and followup for the patient, i.e., the child. This is a complex treatment in which the role of health professionals and healthcare services are crucial to the well-being of children exposed or already infected with HIV ${ }^{(18)}$. The importance of knowing and demystifying the subject related to children born exposed to HIV is revealed, in order to provide them better quality of life.

Furthermore, adverse life circumstances jeopardize the process of structuring personality, the construction of sociability and psychological maturity. As some authors warn, the experiences that occur in childhood are weighted differently in the human life ${ }^{(12,16,18-19)}$. This fact justifies the expansion of research, with the aim of investigating the contexts and quality of life of children, especially those who face unfavorable everyday life situations, to their full and healthy development, such as children exposed to HIV.

\section{Conclusion}

The HIV/AIDS infection is one of the most serious public health problems worldwide, representing a challenge in many ways, especially due to the absence of an effective treatment that leads to healing, as well as social and economic barriers that interfere with the adhesion of the therapeutic regimen.
Considering the assessments performed, this study emphasizes the need for possible follow-up recommended by the Ministry of Health to reduce vertical HIV transmission and healthcare to the individuals born exposed or already infected by the virus. With prevention by the mother during pregnancy and childbirth, achievement of adequate treatment of children in their first months of life, care provided by the mother and the health services, children can have a better quality of life and, consequently, appropriate health conditions.

By knowing the conditions in which children born exposed to HIV live, the significance of these aspects in their lives is understood. Therefore, the attention of family members and health professionals is critical to the physical and emotional well-being of children. Thus, the importance of studies that expose these issues is evidenced, seeking individual effectiveness of health and wellness as well as improvement in public health and well-being of the society, which is constantly exposed and vulnerable to various diseases.

AIDS is confirmed as a stigmatizing disease, which brings a great challenge to family members, health professionals and society. The family becomes obliged to live with many atypical events, like assimilating the fact of having an incurable virus, transmitted to the child, or taking care of a child of a family member who died of AIDS, in addition to often dealing with social prejudice related to the illness. Thus, for the limitations caused by this condition to be addressed in the best possible way, caregivers need to feel safe and supported by health professionals.

There were difficulties in the development of this study, mainly due to the complexity of the subject, which is childhood AIDS. As a limitation, we emphasize the fact that the interview was held on the same day of consultation, so participants were excessively concerned about missing their consultation because of the interview.

Finally, the aspects related to sociodemographic, maternal and clinical conditions of children born 
exposed to HIV were observed, and most had socioeconomic difficulties that could negatively influence their health conditions. Studies of this nature are important to recognize the profile of those affected, so that nursing care directed to existing needs and the resources that these individuals have to live can be determined. Further studies about HIV infection and AIDS in pediatric patients are needed, so that care can be performed according to the unique needs of this group of individuals.

\section{Acknowledgment}

The National Council for Scientific and Technological Development (CNPq), (Protocol N. 570022/2008-8), the Ministry of Health National STD/AIDS Program (Notice 03/2007) for funding and Hospital São José de Doenças Infecciosas for supporting the conduct of the study.

\section{Collaborations}

Galvão MTG contributed to the conception of the study, data collection, analysis, interpretation of data and writing of the article. Cunha GH contributed to data analysis, interpretation, drafting the article and final approval of the version to be published. Freitas JG contributed to data collection. Gir E contributed to discussion, writing of the article and final approval of the version to be published. Reis RK contributed to the discussion, writing of the article and final approval of the version to be published.

\section{References}

1. Lima FLA, Saldanha AAW, Oliveira JSC. Bem-estar subjetivo em mães de crianças sorointerrogativas para o HIV/AIDS. Psicol Rev. 2009; 15(1):141-57.

2. Silva RAR, Rocha VM, Davim RMB, Torres GV. Ways of coping with AIDS: opinion of mothers with HIV children. Rev Latino-Am Enfermagem. 2008; 16(2):260-5.
3. Ministério da Saúde (BR). Secretaria de Vigilância em Saúde. Departamento de DST, AIDS e Hepatites Virais. Boletim Epidemiológico - AIDS e DST. Ano IX $n^{\circ} 01$. Até semana epidemiológica $26^{\underline{a}}$ - junho de 2012. Brasília: Ministério da Saúde; 2012.

4. Cavalcante MS, Silveira ACB, Ribeiro AMS, Ramos Junior AN. Prevenção da transmissão vertical do vírus da imunodeficiência humana: análise da adesão às medidas de profilaxia em uma maternidade de referência em Fortaleza, Ceará. Brasil. Rev Bras Saude Mater Infant. 2008; 8(4):473-9.

5. Ministério da Saúde (BR). Secretaria de Vigilância em Saúde. Programa Nacional de DST e AIDS. Recomendações para profilaxia da transmissão vertical do HIV e terapia antirretroviral em gestantes. Brasília: Ministério da Saúde; 2010.

6. Ministério da Saúde (BR). Secretaria de Vigilância em Saúde. Programa Nacional de DST e AIDS. Recomendações para terapia antirretroviral em crianças e adolescentes infectados pelo HIV. Brasília: Ministério da Saúde; 2009.

7. Barroso LMM, Galvão MTG, Cavalcante RM, Freitas JG. Cuidado materno aos filhos nascidos expostos ao HIV/AIDS. Rev Rene. 2009; 10(4):155-64.

8. Riquinho DL, Gerhardt TE. Necessidades, práticas e apoio social: dimensões subjetivas dos determinantes sociais de saúde. Rev Eletr Com Inf Inov Saúde 2008; 2(2):69-73.

9. Associação Brasileira de Empresas de Pesquisa. Critério de classificação econômica Brasil. [Internet]. 2008 [citado 2012 nov 12]. Disponível em: http://www.abep.org/novo/Content. aspx?ContentID $=139$

10. Cunha GH, Galvão MTG. Nursing diagnoses in patients with human immunodeficiency virus/acquired immunodeficiency syndrome in outpatient care. Acta Paul Enferm. 2010; 23(4):526-32.

11. Assis SG, Avanci JQ Oliveira RVC. Desigualdades socioeconômicas e saúde mental infantil. Rev Saúde Pública. 2009; 43(1):92-100.

12. Galvão MTG, Cunha GH, Rodrigues NLC, Gir E. Aspects of social interactions of HIV-positive children from the perspective of their caregivers. Rev Rene. 2013; 14(1):262-71. 
13. Maksud I. Silêncios e segredos: aspectos (não falados) da conjugalidade face à sorodiscordância para o HIV/AIDS. Cad Saúde Pública. 2012; 28(6):1196-204.

14. Carvalho CML, Galvão MTG. Enfrentamento da AIDS entre mulheres infectadas em Fortaleza - CE. Rev Esc Enferm USP. 2008; 42(1):90-7.

15. Gomes AMT, Cabral IE. Entre dose e volume: o princípio da matemática no cuidado medicamentoso à criança HIV positiva. Rev Enferm UERJ. 2009; 17(3):332-7.

16. Barcellos C, Acosta LMW, Lisboa E, Bastos FI. Surveillance of mother-to-child HIV transmission: so- cioeconomic and health care coverage indicators. Rev Saúde Pública. 2009; 43(6):1006-14.

17. Duarte PS, Ramos DG, Pereira JCR. Padrão de incorporação de fármacos antiretrovirais pelo sistema público de saúde no Brasil. Rev Bras Epidemiol. 2011; 14(4):541-7.

18. Lima AAA, Pedro ENR. Growing up with HIV/ AIDS: a study on adolescents with HIV/AIDS and their family caregivers. Rev Latino-Am Enfermagem. 2008; 16(3):348-54.

19. Galvão MTG, Cunha GH, Machado MMT. Dilemas e conflitos de ser mãe na vigência do HIV/AIDS. Rev Bras Enferm. 2010; 63(3):371-6. 